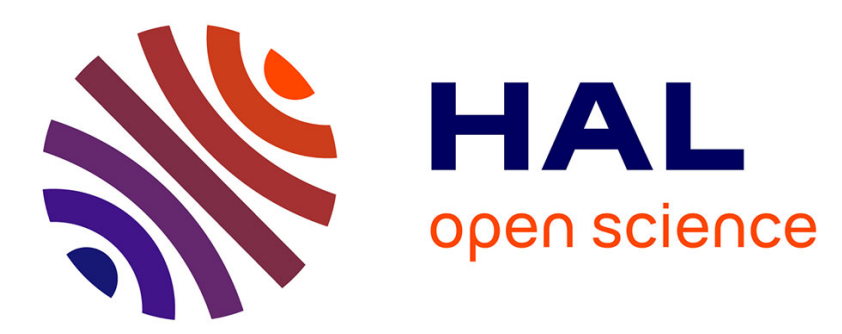

\title{
Application of immobilized bovine enterokinase in repetitive fusion protein cleavage for the production of MUC1
}

Tina Kubitzki, Daniel Minör, Ursula Mackfeld, Marco Oldiges, Thomas Noll, Stephan Lütz

\section{To cite this version:}

Tina Kubitzki, Daniel Minör, Ursula Mackfeld, Marco Oldiges, Thomas Noll, et al.. Application of immobilized bovine enterokinase in repetitive fusion protein cleavage for the production of MUC1. Biotechnology Journal, 2009, 4 (11), pp.1610. 10.1002/biot.200900049 . hal-00508906

\section{HAL Id: hal-00508906 https://hal.science/hal-00508906}

Submitted on 7 Aug 2010

HAL is a multi-disciplinary open access archive for the deposit and dissemination of scientific research documents, whether they are published or not. The documents may come from teaching and research institutions in France or abroad, or from public or private research centers.
L'archive ouverte pluridisciplinaire HAL, est destinée au dépôt et à la diffusion de documents scientifiques de niveau recherche, publiés ou non, émanant des établissements d'enseignement et de recherche français ou étrangers, des laboratoires publics ou privés. 


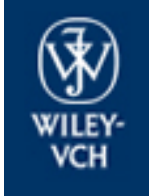

Biotechnology Journal

\section{Application of immobilized bovine enterokinase in repetitive fusion protein cleavage for the production of MUC1}

\begin{tabular}{|c|c|}
\hline Journal: & Biotechnology Journal \\
\hline Manuscript ID: & biot.200900049.R2 \\
\hline Wiley - Manuscript type: & Research Article \\
\hline $\begin{array}{r}\text { Date Submitted by the } \\
\text { Author: }\end{array}$ & 02-Jul-2009 \\
\hline Complete List of Authors: & $\begin{array}{l}\text { Kubitzki, Tina; Forschungszentrum Jülich, Institut für } \\
\text { Biotechnologie } 2 \\
\text { Minör, Daniel; Forschungszentrum Jülich, Institut für Biotechnologie } \\
2 \\
\text { Mackfeld, Ursula; Forschungszentrum Jülich, Institut für } \\
\text { Biotechnologie 2 } \\
\text { Oldiges, Marco; Forschungszentrum Jülich, Institut für } \\
\text { Biotechnologie 2 } \\
\text { Noll, Thomas; Universität Bielefeld, Technische Fakultät } \\
\text { Lütz, Stephan; Forschungszentrum Jülich, Institut für } \\
\text { Biotechnologie 2; Novartis, GDC/PSB/BIR }\end{array}$ \\
\hline Keywords: & $\begin{array}{l}\text { enterokinase, immobilization, fusion protein cleavage, protein } \\
\text { purification, MUC1 }\end{array}$ \\
\hline
\end{tabular}

\section{s) ScholarONE" \\ Manuscript Central}


1

2

3

4

5

6

7

8

9

10

11

12

13

14

15

16

17

18

19

20

21

22

23

24

25

26

27

28

29

30

31

32

33

34

35

36

37

38

39

40

41

42

43

44

45

46

47

48

49

50

51

52

53

54

55

56

57

58

59

60

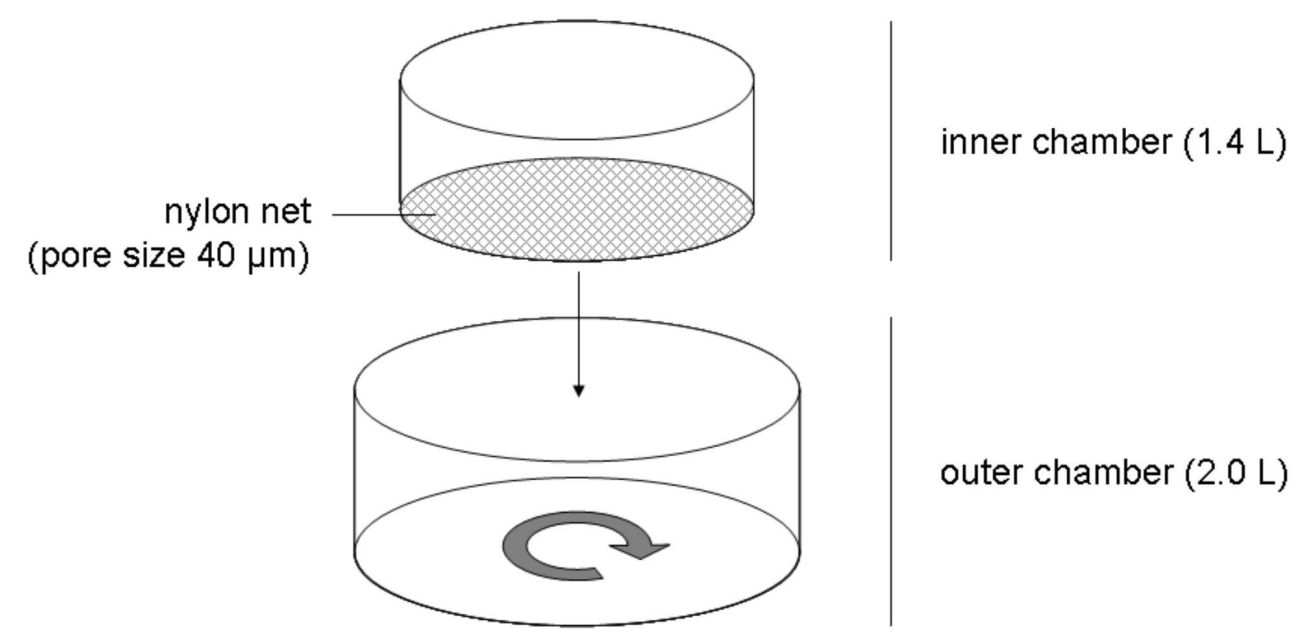

Scheme of the batch binding chamber used for enterokinase purification with metal chelate affinity chromatography. $169 \times 83 \mathrm{~mm}(600 \times 600 \mathrm{DPI})$ 


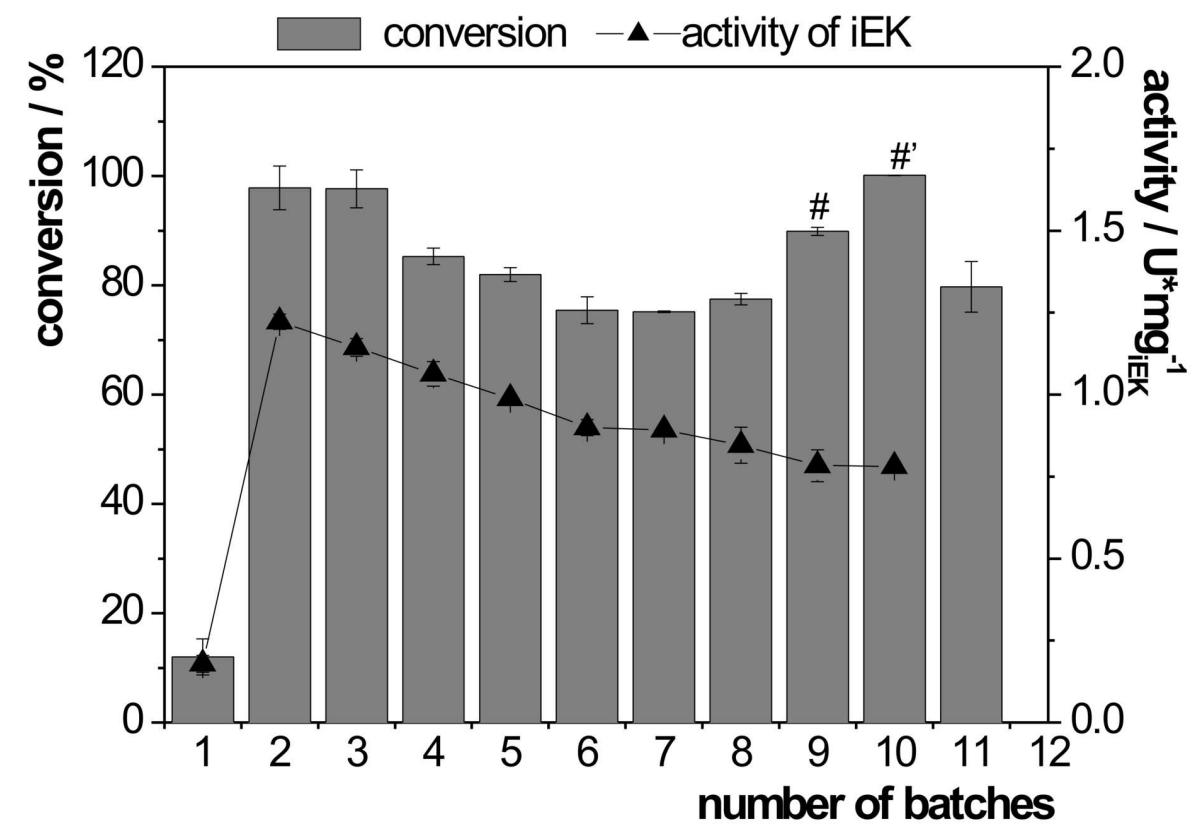

Application of immobilized enterokinase in repetitive fusion protein cleavage. The reaction solution was removed after $24 \mathrm{~h}$ (increased process time of $27 \mathrm{~h} \mathrm{( \# )} \mathrm{and} 33 \mathrm{~h}\left(\#^{\prime}\right)$ ) and new substrate solution was added to the enzyme-support preparation starting a new cleavage reaction. The set reaction conditions involved $1.16 \mathrm{mg} * \mathrm{~mL}-1 \mathrm{MUC1}-\mathrm{IgG} 2 \mathrm{a} \mathrm{Fc}$ in $50 \mathrm{mM}$ Tris- $\mathrm{HCl}, \mathrm{pH} 8.0$ incubated with $10 \mathrm{U} *$ gcarrier-1 (determined with GD4K-2NA) immobilized enterokinase in a reaction volume of $1 \mathrm{~mL}$ at $25^{\circ} \mathrm{C}$ under shaking conditions. $87 \times 63 \mathrm{~mm}(600 \times 600 \mathrm{DPI})$ 

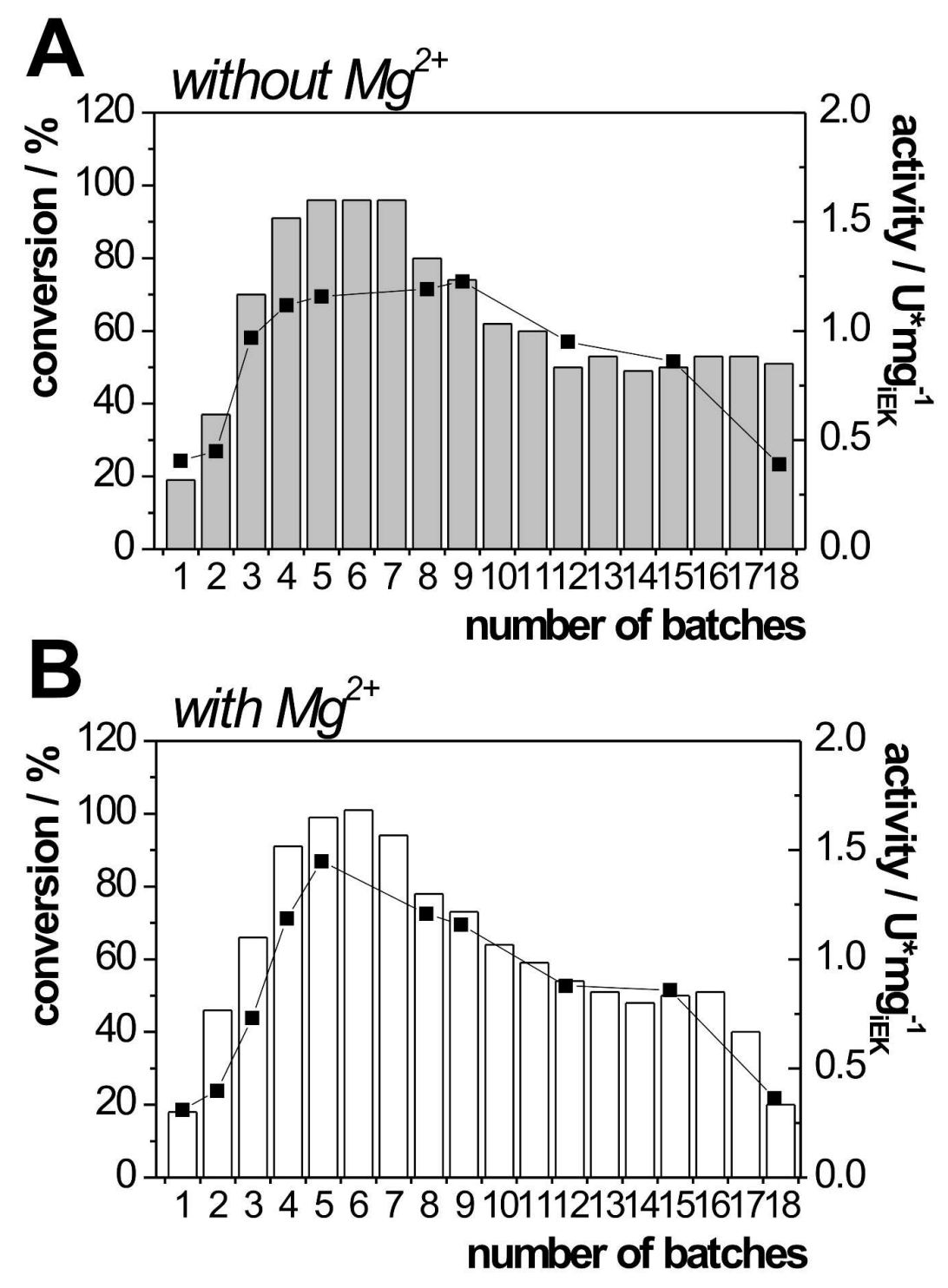

Repeated fusion protein cleavage by immobilized enterokinase in the absence and presence of magnesium. The reaction solution was removed after $24 \mathrm{~h}$ and new substrate solution was added to the enzyme-support preparation starting a new cleavage reaction. The set reaction conditions involved $0.625 \mathrm{mg} * \mathrm{~mL}-1 \mathrm{MUC1}-\mathrm{IgG} 2 \mathrm{a} \mathrm{Fc}$ in $50 \mathrm{mM}$ Tris- $\mathrm{HCl}, \mathrm{pH} 8.0$ incubated with $10 \mathrm{U} * \mathrm{~mL}$ $1 *$ gcarrier-1 (determined with GD4K-2NA) immobilized enterokinase in a reaction volume of $1 \mathrm{~mL}$ at $25^{\circ} \mathrm{C}$ under shaking conditions. The reaction buffer was supplemented with $1 \mathrm{mM}$ magnesium ions.

A) Repetitive batches in the absence of magnesium; B) Repetitive batches in the presence of magnesium. $125 \times 168 \mathrm{~mm}(600 \times 600 \mathrm{DPI})$ 